\title{
Molecular genotyping of Anisakis Dujardin, 1845 (Nematoda: Ascaridoidea: Anisakidae) larvae from marine fish of Balinese and Javanese waters, Indonesia
}

\author{
H. W. Palm ${ }^{1 *}$, I. M. Damriyasa ${ }^{2}$, Linda ${ }^{2}$, I. B. M. Oka ${ }^{2}$
}

\author{
${ }^{1}$ Heinrich-Heine-University Düsseldorf, Institute of Zoomorphology, Cell Biology and Parasitology, \\ Universitätsstrasse 1, 40225-Düsseldorf, Germany, E-mail: hpalm@indo.net.id $;{ }^{2}$ Udayana University, Bukit Jimbaran, \\ 80363-Badung, Bali, Indonesia
}

\begin{abstract}
Summary
The genetic identification and distribution of Anisakis larvae in Indonesia is described. 110 Auxis rochei rochei and 45 Decapterus russellii were sampled from fish markets in North (Anturan) and South (Kedonganan) Bali. Nematode larvae from A. rochei rochei, Caesio cuning and Epinephelus areolatus from Kedonganan and from Coryphaena hippurus from Pelabuhan Ratu, South Java, were identified using sequence analysis of the internal transcribed spacers (ITS-1, ITS-2) and 5.8S region of rDNA. The larvae belonged to Anisakis typica with an identical sequence to this species from the spinner dolphin (Stenella longirostris) from Brazil, and to 2 further genotypes that differed from that sequence by $0.24-0.47 \%$. A. typica occurred in the migratory $A$. rochei rochei and $C$. hippurus, while Anisakis sp. 1 and 2 were isolated from the same fish species and the non-migratory C. cuning and E. areolatus. The latter genotype is distinguishable by 4 positions in the ITS-1 region (1.1\%), a genetic distance that indicates the presence of an Indonesian A. typica sibling species. The musculature infection in $A$. rochei rochei was low $(2.5 \%)$, indicating no major risk for the fish consumers. The much higher A. typica infection of fish intermediate hosts in the northern Bali coast is suggested to be dependent on the large dolphin population (nematode final hosts) in the waters off Lovina Beach (North Bali).
\end{abstract}

Keywords: Anisakis typica; Bali; Java; Indonesia; molecular genotyping; sibling species; zoogeography

\section{Introduction}

In Indonesia, as a maritime country, fisheries and fish products play an important role in the economic development, both of local communities and as a highly valuable export commodity. Fish food is also of major importance for the Indonesian tourism industry. As such, fish health and fish hygiene are of high significance for consumers, fisheries and the local fish processing industry. Zoonoses mainly originate from helminths, that utilize finfish as intermediate and marine mammals as final hosts. They are able to survive inside the human digestive tract. A spectrum of disease causing zoonotic fish worms is known. The most recognized and widely distributed are nematodes of the genus Anisakis (Anisakidae, Ascaridoidea). This cosmopolitan genus is known to cause the human anisakiasis, a painful inflammation of the gastro-intestinal tract (Ishikura \& Namiki, 1989; Ishikura \& Kikuchi, 1990). The most common in tropical waters is Anisakis typica, a species that has been recently genetically identified from the South West Atlantic (Brazil, Nadler et al., 2005), North West Atlantic (Florida, Mattiucci et al., 2005) and the Mediterranean (North Africa, Farjallah et al., 2007).

Marine fish parasitology in Indonesia is widely undeveloped, and the local literature is not recognized outside the country. The first comprehensive fish parasitological examinations of marine finfish started with the discovery of several new species in South Sulawesi waters (Yamaguti, 1952, 1953a, b, 1954a, b, c, d). Hadidjaja et al. (1977), Hutomo et al. (1978) and Ilahude et al. (1978) studied anisakid nematodes from East Sumatra and the North Java coast, and Burhanuddin and Djamali (1978) used anisakid nematodes for stock separation in the roundscad Decapterus russelli in the Java Sea. Ilahude et al. (1978) and Burhanuddin and Djamali (1983) recorded 23 different fish species from the northern Java coast that were infected with anisakid nematodes, among these 4 different Epinephelus species. However, no infection was recorded from the fish musculature, most probably due to the study of fish preserved in $10 \%$ formalin. Palm $(2000,2004)$ mainly focused on commercially important fish parasitic cestodes belonging to the Trypanorhyncha (Cestoda) from South Java. The author reported that Indonesia is at the centre of the diversity of this group of fish worms, and predatory fish especially can be highly infected. Lester et 
al. (2001), Moore et al. (2003) and Latama (2006) used fish parasites to distinguish between Indonesian and Australian stocks of the narrow-barred Spanish mackerel Scomberomorus commerson, and Jakob and Palm (2006) studied 5 commercially important fish species off the south-western Java coast for fish parasites. The latter recorded 38 different parasite species, among these was Anisakis sp., reaching a prevalence of $100 \%$. Yuniar et al. (2007) studied 8 commercially important fish parasites in the only remaining large mangrove ecosystem in southern central Java, and recorded 23 ectoparasitic crustaceans and 27 endoparasitic metazoans. More than 400 different parasite species have been recorded so far from Indonesian marine waters (Jakob \& Palm, 2006; Rückert, 2006; Yuniar et al., 2007).

Fish parasitological studies in Bali are scarce. Because of the importance of parasites in finfish mariculture, information is available on grouper (e.g. Cromileptes altivelis) parasites from net cages at the Gondol Research Station in North Bali (Yuasa et al., 1998; Zafran et al., 2000). Koesharyani et al. (2001) presented the first record of anisakid nematodes from $C$. altivelis and Plectopomus leopardus from Bali. Besides mariculture, the Balinese economy is heavily dependent on international tourism. The Balinese people themselves and the tourists appreciate the freshness and high diversity of marine food fish. However, some dishes such as Sushimi or Surimi from Japan and Kinilaw from the Philippines (Petersen et al., 1993), if practiced in Bali, bear the risk of transmitting zoonotic fish parasites to the consumer. Similarly, the traditional North Sulawesi dish 'gohu cakalang' of raw fish, spiced with citrus or lemon juice, might bear risks for the fish consumers. A wide variety of different fish dishes is a speciality in the vicinity of the Kedonganan fish market at the southern Bali coast.

If known to doctors as a potential threat, anisakiasis can be easily detected and is no major human health problem due to proper treatment. However, so far, no data do exist on the occurrence of the zoonotic Anisakis in Balinese waters, and no record exists on anisakid musculature infection. The real identity of the Anisakis in Indonesian waters is still unknown. The purpose of the present study was 1) to identify a possible human health risk from free living finfish from Bali caused by the marine fish nematode Anisakis; 2) a molecular genotyping of Anisakis from Balinese and adjacent waters; 3) to analyse two pelagic marine fish species of similar size and trophic level from public fish markets in South (Kedonganan) and North Bali (Anturan) for prevalence and intensity of infection with anisakid nematodes.

\section{Material and methods}

\section{Parasitological examination}

Fish $(\mathrm{n}=115)$ belonging to the scombrid Auxis rochei rochei (70 specimens) and the carangid Decapterus russelli (45 specimens) were examined for larval Anisakis sp. in the body cavity and internal organs in May - December
2005. A second sample of 40 specimens of Auxis rochei rochei was studied in October - November 2006 for infection with Anisakis in the body cavity, internal organs and musculature to detect annual variation. The fish were obtained fresh from the local fish markets in Kedonganan (South Bali, 35 A. rochei rochei and 35 D. russelli in 2005, and $40 \mathrm{~A}$. rochei rochei in 2006) and Anturan (North Bali, $35 \mathrm{~A}$. rochei rochei and $10 \mathrm{D}$. russelli in 2005), and transported on ice to the laboratory of the Faculty of Veterinary Sciences, Parasitology Laboratory, Udayana University, Denpasar, for further investigation. In the laboratory, the standard length to the nearest $\mathrm{cm}$ was recorded for each fish before examination. The body cavity was opened and studied by naked eye, the internal organs were separated and all parasites were removed. The musculature was sliced into $0.5-1 \mathrm{~cm}$ thick filets, pressed between 2 petridishes until they became translucent, and studied against a strong light source. The living Anisakis sp. were easily identifiable by the large white ventricle behind the oesophagus and the lack of any appendices. The ecological parameters were taken according to Bush et al. (1997). The fish was screened for the stomach contents after the parasitological examination.

Isolation of genomic DNA, PCR amplification and sequencing of ITS-1, 5.8S and ITS-2

Nematodes isolated from the examined fish were identified morphologically by existing keys and descriptions as belonging to the genus Anisakis (as described in section 2.1, Anderson 2000). They were then fixed and stored in $100 \%$ ethanol. Eight specimens of $A$. typica from $A$. rochei rochei from Kedonganan fish market collected in 2006 were used for molecular identification. They were compared with 9 specimens from Caesio cuning and 3 specimens from Epinephelus areolatus from the same market and sampling period in November 2006. Seven Anisakis larvae were collected in June 2006 from Coryphaena hippurus from Pelabuhan Ratu, south-western Java coast.

Genomic DNA was isolated and purified from individual larvae by using a genomic DNA extraction kit (Peqlab Biotechnology $\mathrm{GmbH}$, Erlangen, Germany) according to the instructions of the manufacturer. The rDNA region comprising the ITS-1, 5.8S, ITS-2 and flanking sequences (=ITS + ) was amplified by using the previously described primers NC5 (5'-GTA GGT GAA CCT GCG GAA GGA TCA TT-3') and NC2 (5'-TTA GTT TCT TTT CCT CCG CT-3') (Zhu et al., 2000). PCR-reactions (26 $\mu \mathrm{l})$ included $13 \mu$ l Master-Mix (Peqlab Biotechnology GmbH, Erlangen, Germany) containing dNTP, $\mathrm{MgCl}_{2}$, Buffer and Taq-Polymerase, $3 \mu \mathrm{l}$ of each primer, $2 \mu \mathrm{l}$ water and $5 \mu \mathrm{l}$ genomic DNA. Each PCR reaction was performed in a thermocycler (Biometra, Germany) under the following conditions: after initial denaturation at $95^{\circ} \mathrm{C}$ for $15 \mathrm{~min}, 30$ cycles of $94{ }^{\circ} \mathrm{C}$ for $1 \mathrm{~min}$ (denaturation), $55^{\circ} \mathrm{C}$ for $1 \mathrm{~min}$ (annealing), 72 ${ }^{\circ} \mathrm{C}$ for $1 \mathrm{~min}$ (extension), followed by a final extension at $72{ }^{\circ} \mathrm{C}$ for $5 \mathrm{~min}$. Samples without DNA were included in each PCR run. PCR products were examined on $1 \%$ agarose gels. A 100 bp ladder marker (Peqlab Biotechnology 
$\mathrm{GmbH}$, Erlangen, Germany) was used to estimate the size of the PCR products. To identify the anisakid nematodes, the PCR products were purified with E.Z.N.A. Cycle-Pure Kit (Peqlab Biotechnology GmbH, Erlangen, Germany). Afterwards a total volume of $7 \mu \mathrm{l}$, including $2 \mu \mathrm{l}$ primer (individually) and $5 \mu \mathrm{l}$ of the PCR product $(\sim 250 \mathrm{ng} / \mu \mathrm{l})$ were sequenced by Seqlab (Goettingen $\mathrm{GmbH}$, Germany). Both spacers and the 5.8S gene were sequenced in both directions from each PCR product, using primers $\mathrm{NC5}$, NC13 (forward; 5'-ATC GAT GAA GAA CGC AGC-3'), NC13R (reverse; 5'-GCT GCG TTC TTC ATC GAT-3'), XZ1R (reverse; 5'-GGA ATG AAC CCG ATG GCG CAA T-3') and NC2.

\section{Alignment}

The sequences (forward and reverse) of the ITS-1, 5.8S and ITS-2 region were assembled and edited using Bio Edit Sequence Alignment Editor (V 7.0.5.3). They were compared manually with the original chromatograms, identified via GenBank and aligned with a previously characterized sequence (GenBank) of Anisakis typica from the spinner dolphin (Stenella longirostris) from Brazil (AY826724, see Nadler et al. 2005), using CLUSTAL W (1.83) Multiple Sequence Alignments (Thompson et al. 1994). Nucleotide sequence data are available in the GenBank database under the accession numbers EU346091-3. They were then aligned with sequences from other Anisakis species from Genbank; A. brevispiculata (AY826719) from Kogia breviceps in Florida, A. pegreffii (AB277823) from a mackerel and $A$. simplex (AB277822) from the arabesque greenling in Japan, A. simplex ' $\mathrm{C}$ ' (AY821739) from Mirounga angustirostris in California, and A. ziphidarum (AY826725) from Ziphius cavirostris in South Africa. Genetic distances were determined and a phylogenetic tree was calculated with the optimality criterion set to distance and the UPGMA algorithm using PAUP* (Swofford 2001).

\section{Results}

\section{Genetic identification}

The informative gene products for larval Anisakis identification from Indonesia were 844 base pairs long and comprised most part of the ITS-1 (Fig. 1), $5.8 \mathrm{~S}$ and partial ITS-2. They were $0.00-0.47 \%$ different in sequence to adult $A$. typica from the spinner dolphin (S. longirostris) from Brazil, with a $0.84-2.0 \%$ difference in the partial ITS-1 region (355 informative bp) and a $0.35-0.83 \%$ difference $(3-7 \mathrm{bp})$ in the complete gene product ( $844 \mathrm{bp}$ ) including 3 deletions. Genetic distances among different Anisakis species compared to the Indonesian Anisakis typica by using 903 informative base pairs resulted in the same genetic distance of the sibling species Anisakis simplex (s.s) and A. simplex C (4 bp) for the whole gene product than that observed for $A$ typica from Brazil/Indonesia and Anisakis sp. 2 in the ITS1-region (Table 1, Fig. 2). No other Anisakis species could be identified.
Two most frequent genotypes were identified as $A$. typica and Anisakis sp. 2 (Figs 1,2). A. typica occurred in the migratory fish $A$. rochei rochei (4 from 8 specimens) and in $C$. hippurus (one specimen infected). It differed in 3 positions (solely deletions) in the ITS-1 from the Brazilian material (Fig. 1), the rest of the sequences of the $5.8 \mathrm{~S}$ and ITS-2 were identical. The predominant genotype Anisakis sp. 2 (21 of 27 studied Anisakis) was found in the nonmigratory C. cuning and E. areolatus (all studied Anisakis in these fish belonged to this type) and also in $A$. rochei rochei and $C$. hippurus (Fig. 1). It differed in 7 positions in the ITS-1 region from the sequence of the spinner dolphin, including the 3 deletions that were also observed in the other specimens. A third genotype (Anisakis sp. 1) was isolated in a single case from $A$. rochei rochei. It had an intermediate position, and differed in 5 positions in the ITS-1 from A. typica from Brazil and in 2 positions from both other genotypes, respectively.

The $5.8 \mathrm{~S}$ of all specimens was identical with the sequence of $A$. typica from Brazil, and minor variation was found in 2 positions (781 G vs R, $811 \mathrm{~T}$ vs C) of the ITS-2 in 3 specimens of $A$. typica from Indonesia. No further variation was observed.

Parasite infection: Data on A. typica and Anisakis sp. 1 and 2 infection in fish from Indonesia are given in tables $2-4$. Because it is not possible to morphologically distinguish between these genotypes, the tables refer to a mixed genotype infection (see discussion).

Both studied fish species were infected with Anisakis spp. in the body cavity and internal organs. The number of larval Anisakis increased with fish standard length, with no difference in the intensity of infection in male and female fish. Most Anisakis specimens were collected from the $A$. rochei rochei sampled in the North (Anturan) compared to the South (Kedonganan) of Bali (see Tab. 2). In contrast, the less infected Decapterus russelli had a higher prevalence and intensity in the South compared to the North of Bali (Table 2). The study of $A$. rochei rochei in 2006 revealed a lower infection compared to 2005 .

Within both years, Anisakis spp. appeared to be evenly distributed within the organs. The most heavy infection occurred in the mesentery and attached to the intestinal wall (Tab. 3). The gonads, liver and body cavity were also infected with a prevalence higher than $25 \%$. This picture was similar between the fish hosts and sampled years. The musculature of $A$. rochei rochei harboured only a single specimen of $A$. typica in one out of 40 sampled hosts $(2.5 \%)$ (investigated only in 2006).

Other observation: In addition to A. typica and 2 related genotypes, three other fish parasite species were isolated from $A$. rochei rochei and $D$. russelli. Most abundant was the acanthocephalan Rhadinorhynchus sp. (cf celebesensis Yamaguti 1954b) in the intestine of $A$. rochei rochei. Undeveloped larval stages of an unidentified cestode were collected from the body cavity of $A$. rochei rochei, and a single larval specimen of the raphidascarid nematode 


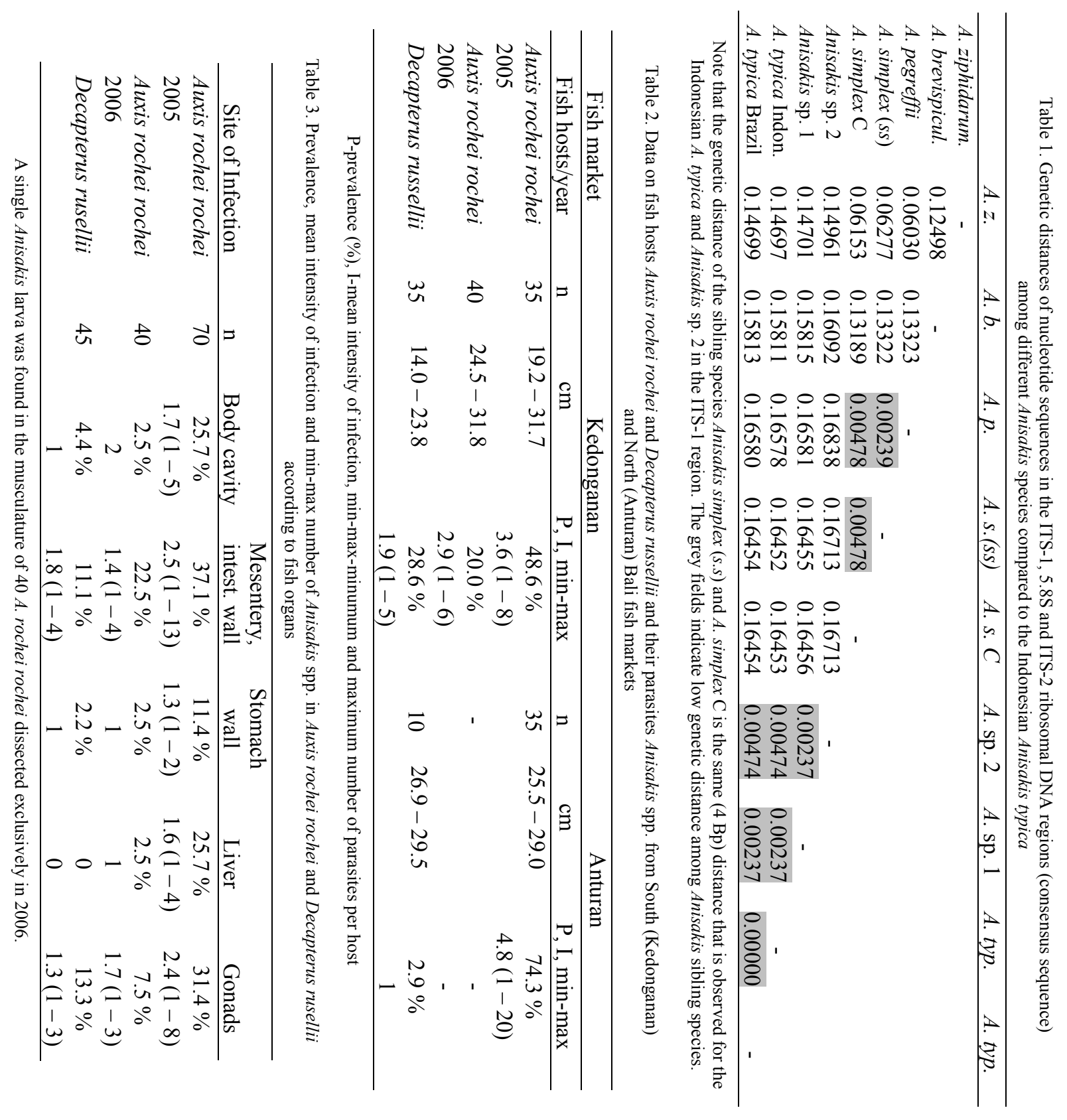


苛

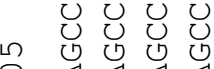

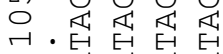
出出出 兒兒兒兒 0 ৩

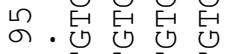
E 舁舁舁舄

芯这芯通

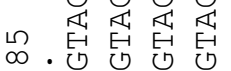
OU U U

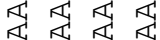
管算筫 ค.

芯芯芯芯

u u u

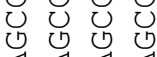
芯出芯芯

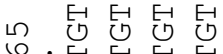

. 弁帠兒兒 兒兒兒兒

是是是 ص. U⿺辶寸

䀝䀝䀝

筧芯怎

0 O 00

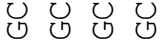
电. U U U U U

兒兒兒

O)

鼠兒兒舅

U U U

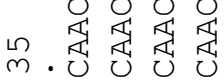

1

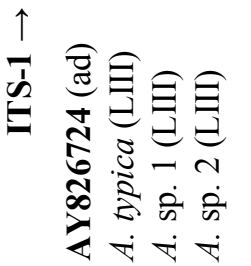

नें

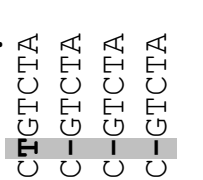

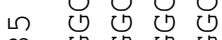

$\infty$.

帠䀝䀝

发这

U⿺辶寸

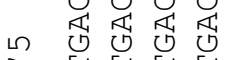

ㄱ. ․ㅓㅂ법법

게 0

在在在庭

U U

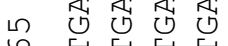

r. 旨舅舅舅

버법

O O

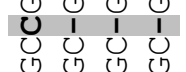

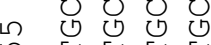

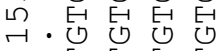

兒

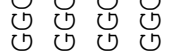

텅법법

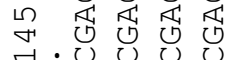

还宕足

䀝舅舅舅

O

0 O 0

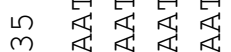

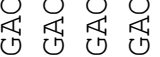

质延

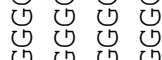

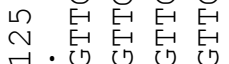

0 O 0

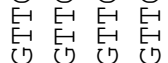

㓠皆

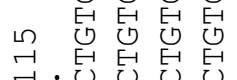

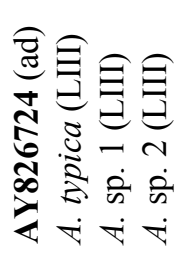

$\stackrel{r}{\sim}$

兒兒兒兒

U 出开

质芯

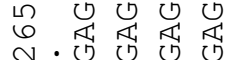

E E E E

品兒界

芯岱芯

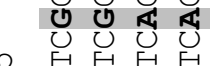

员.

텁ㅌㅂ

$\checkmark 000$

舁兒舁

瓜安是

+ 芯出忍式

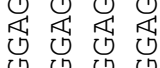

0 O 0

텁

约出出芯

N. 座安

芯出出芯

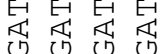

U U U U

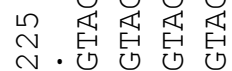

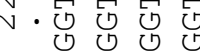

U

O

U U U

吕

N.법뷔법

0 O

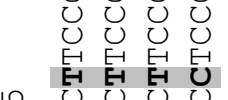

ᄂ

‥

兒兒兒兒

E E E E

昏昏昏

OU O

ने.

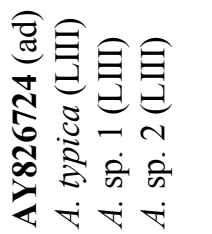

藏.

舅舅

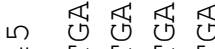

m. 是旡崫

번붕

芯思芯

兒舄䀝舅

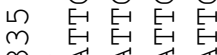

·芯通芯䢑

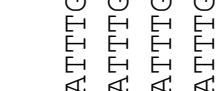

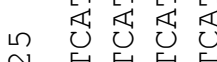

N. 旨舁舁兒

旨舅舅舅

텁

焉是是

n U U U U

$m \cdot$. 近

还否

在安

在否发

ก)

U U U U

笮芯近筫

芯造芯通

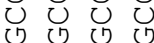

ค

垈

舁舄兒舅

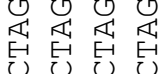

目兒兒兒

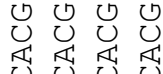

U

웜

芯芯哲芯

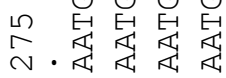

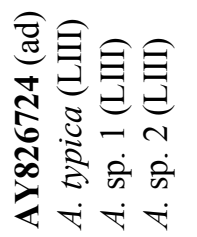

$\frac{\mathscr{b}}{\mathscr{0}}$

象

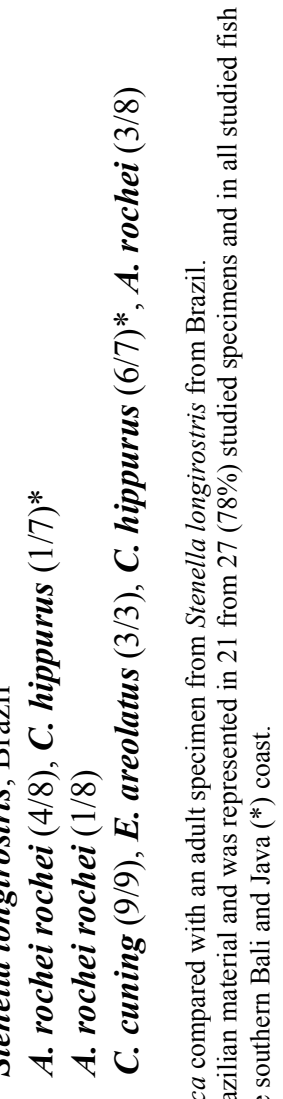

$\infty$

可

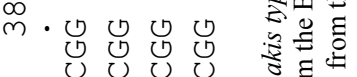

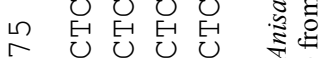

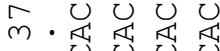

论 U U

舁思惥惥

○ O 0 O

舄舁舄兒

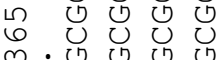

吕

舅帠舁舁

记

瓜近

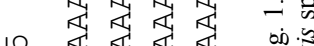

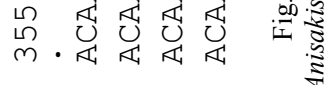

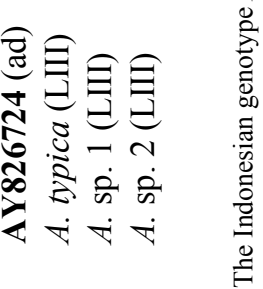


Raphidascaris sp. was found in the body cavity of $D$. russelli (also see Yamaguti 1954a). Both studied fish species had their stomachs filled with small crustaceans, and only A. rochei rochei harboured small fish with a maximum length of appr. $3 \mathrm{~cm}$. A single specimen of the digenean Hirudinella ventricosa (Baird, 1853) was isolated from the stomach of Auxis thazard thazard (Lacepède, 1800), also from Kedonganan fish market.

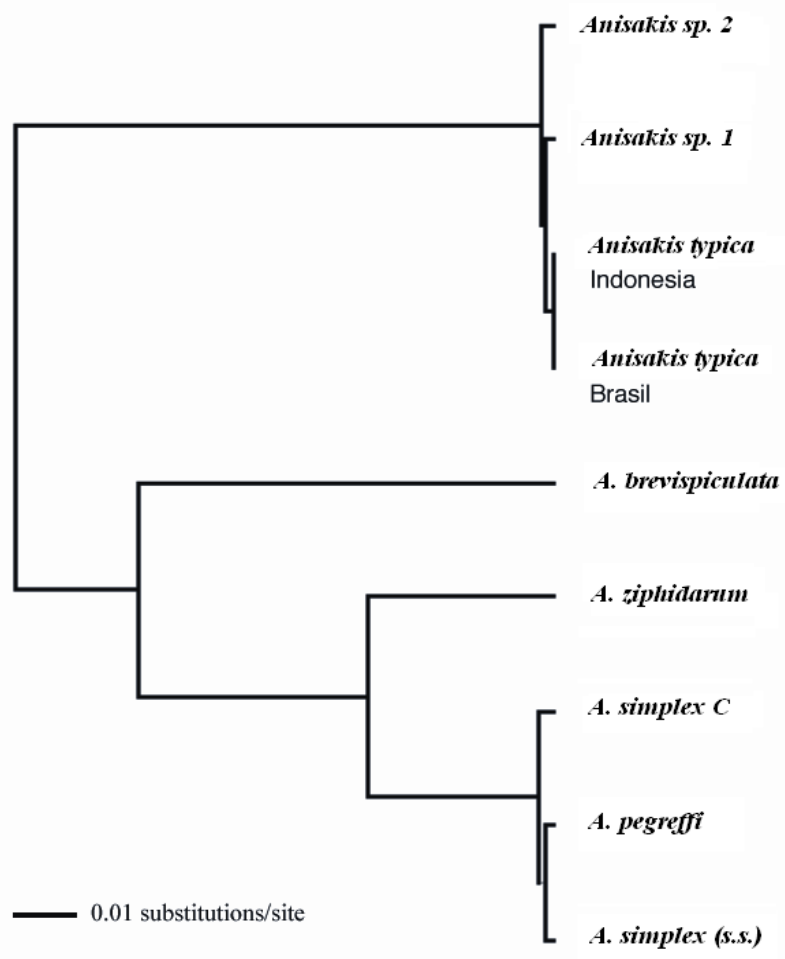

Fig. 2. Phenogram depicting the genetic differences (upon pairwise comparison) among the Indonesian Anisakis typica and different Anisakis species for the ITS-1, 5.8S and ITS-2 rDNA sequence.

\section{Discussion}

The present study provides the first molecular identification of anisakid fish nematodes from Balinese waters, Indonesia. The identified specimens belonged to Anisakis typica and to two closely related genotypes (here named Anisakis sp. 1 and 2). A. typica is a common parasite of various dolphin species from warmer temperate and tropical waters, belonging to the families Delphinidae, Phocoenidae and Pontoporidae (see Mattiucci et al., 2002). Mattiucci et al. (2002) recorded larval A. typica from Auxis thazard thazard and Thunnus thynnus from the Brazilian coast (SW Atlantic), Scomber japonicus and Trachurus picturatus from the NE Atlantic off Madeira, Euthynnus affinis, Scomberomorus commerson, Sarda orientalis and Coryphaena hippurus from the West Indian Ocean off Somalia, and from Merluccius merluccius from the Eastern Mediterranean Sea. Further records were provided by Mattiucci et al. (2005) from Florida (Stenella attenuata, Globicephala macrorhynchus, Mesoplodon sp. as final hosts) and Farjallah et al. (2007) from the Mediterranean coast of North Africa (Scomber scombrus, M. merluccius,
Phycis phycis as intermediate hosts).

The present study adds new locality records from the southern Balinese and Javanese coast, East Indian Ocean (Table 4), and a new host record for Auxis rochei rochei. A new genotype that might represent a sibling species of $A$. typica was identified from $A$. rochei rochei, $C$. cuning, $C$. hippurus and E. areolatus. The records of Anisakis sp. from the gempylids Gempylus serpens and Thyrsitoides marleyi, the trichiurid Trichiurus lepturus and the bramid Brama dussumieri by Jakob and Palm (2006) came from the same locality than the specimens isolated from $C$. $h i$ ppurus in the present study, and might also represent these genotypes. Thus, larval $A$. typica or closely related siblings (see below) infest a wide range of clupeiform, perciform and also gadiform fish in warmer waters, and seem to be the most common anisakid in the Indonesian region. A total of 21 fish species are known to harbour Anisakis spp. or A. typica in Indonesia, with 34 fish species known to be infected with anisakid nematodes (Table 4).

Three different genotypes of anisakid nematodes could be identified, differing in $3-7$ base pairs in the ITS-1 region from an adult specimen from the spinner dolphin ( $S$. longirostris) from Brazil. While the migratory fish $C$. hippurus and $A$. rochei rochei harboured specimens of $A$. typica that was very similar compared with the Brazilian material (differed in 3 deletions in the ITS-1), most isolated specimens $(78 \%)$ and all those from the non-migratory $C$. cuning and E. areolatus belonged to an Indonesian genotype (Anisakis sp. 2) that consistently differed in 4 base pairs of the ITS-1. Within the former type, only 3 specimens varied by a single base pair in the ITS- 2 regions, indicating a high homogeneity of all genetically identified Anisakis specimens from Indonesia. Mattiucci et al., (2002) already stated a high similarity of her studied specimens, despite being geographically quite distant. Kellermanns et al. (2007) suggested that a constant gene flow in different anisakid nematodes is caused by a) extensive final host migration in the case of A. simplex (s.s.), b) an overlapping distribution of final host populations along the continental shelves for Pseudoterranova decipiens (s.s.), and c) a low host specificity and large population size in the intermediate and final hosts for Hysterothylacium aduncum. Palm et al. (2007) suggested d) extensive final as well as intermediate host migration as being responsible for a high gene flow in a cosmopolitan fish cestode, the trypanorhynch Tentacularia coryphaenae. A. typica, as a tropical anisakid, seems to follow the latter dispersal mechanism, being more similar to the trypanorhynch than to the congener A. simplex (s.s.), as can be seen in highly overlapping fish intermediate hosts in the tropics (Table 4 vs Palm, 2004). More extensive studies from other fish hosts and Indonesian localities and possibly other gene regions are needed in order to clarify the occurrence of other Anisakis species in Indonesian waters, and to determine that the observed differences in the ITS-1 represent normal intraspecific variation or are a characteristic of a possibly existing Indonesian A. typica sibling species. The $4 \mathrm{bp}$ difference is of the same range than re- 
corded for the siblings $A$. simplex (s.s.) and A. simplex $\mathrm{C}$ as well as $A$. pegreffii (Fig. 2).

The life cycle of $A$. typica involves dolphins as final hosts that harbour the $4^{\text {th }}$ stage larva and adult (Mattiucci et al., 2002). The nematode eggs of the congener A. simplex (s.s.) leave their hosts with the faeces and embryonate in seawater (e.g. Klimpel et al., 2004; Kellermanns et al., 2007). Larvae hatch as free living third-stage larvae (L3), still surrounded by the sheath of the second-stage larvae (L2), and get eaten by small crustaceans (copepods, euphausiids)

Table 4: Host records of Anisakis from Indonesia. Anisakis sp. 1-2 might represent a local variation of $A$. typica or a sibling species in Indonesian waters (explanation see text)

\begin{tabular}{|c|c|c|c|c|}
\hline Fish species & Family & Parasite & Locality & Reference \\
\hline Atule mate & Carangidae & Anisakis sp. & N Java & 1,2 \\
\hline Caranx crumenophthalmus & 6 & Anisakis sp. & “ & 1,2 \\
\hline Brama dussumieri & Bramidae & Anisakis sp. & S Java & 3 \\
\hline Decapterus kurroides & “ & Anisakidae & N Java & 4 \\
\hline D. lajang & “ & Anisakis sp. & “ & 4,5 \\
\hline D. russelli & “ & $\begin{array}{l}\text { Anisakis sp. } \\
\text { (typica, 1-2?) }\end{array}$ & Bali, Java & $\begin{array}{c}4,5,6,7,8 \\
\text { present study }\end{array}$ \\
\hline Caesio cuning & Caesionidae & Anisakis sp. 2 & Bali & Present study \\
\hline Amblygaster sirm & Clupeidae & Anisakis sp & $\begin{array}{c}\text { N Java, } \\
\text { Sunda Strait }\end{array}$ & $4,5,7,8$ \\
\hline Sardinella fimbriata & “ & Anisakidae & “ & 4 \\
\hline S. gibbosa (=jussieui) & “ & Anisakis sp. & “ & 1,2 \\
\hline Coryphaena hippurus & Coryphaenidae & $\begin{array}{l}\text { A. typica \#, } \\
\text { Anisakis sp. } 2\end{array}$ & S Java & Present study \\
\hline Gempylus serpens & Gempylidae & Anisakis sp. & “ & 3 \\
\hline Thyrsitoides marleyi & “ & Anisakis sp. & ، & 3 \\
\hline Leiognathus dussumieri & Leiognathidae & Anisakis sp. & Sulawesi & 9 \\
\hline Lutjanus kasmira & Lutjanidae & Anisakidae & N Java & 2 \\
\hline Auxis thazard thazard & Scombridae & Anisakidae \# & “ & 4 \\
\hline A. rochei rochei & “ & $\begin{array}{c}\text { A. typica, } \\
\text { Anisakis sp. 1-2 }\end{array}$ & Bali & Present study \\
\hline Euthynnus affinis & “ & Anisakis sp. \# & N Java & 1,4 \\
\hline Rastrelliger brachysoma & “ & Anisakis sp. & “ & 1,2 \\
\hline R. kanagurta & “ & Anisakis sp. & “ & $4,5,7,8$ \\
\hline Scomberomorus commerson & “ & $\begin{array}{l}\text { Anisakidae \#*, } \\
\text { A. simplex * }\end{array}$ & Kupang & 4,10 \\
\hline Cromileptes altivelis & Serranidae & Anisakidae & Bali & 11 \\
\hline Epinephelus areolatus & “ & Anisakis sp. 2 & “ & Present study \\
\hline E. fuscoguttatus & “ & Anisakis sp. & $\begin{array}{l}\text { N Java, } \\
\text { Sulawesi }\end{array}$ & 4,12 \\
\hline E. maculatus & “ & Anisakidae & ، & 4 \\
\hline E. quoianus (=megachir) & “ & “ & “ & 4 \\
\hline E. summana & “ & “ & “ & 4 \\
\hline Plectopomus leopardus & “ & Anisakis sp. & $\begin{array}{c}\text { Bali, } \\
\text { Sulawesi }\end{array}$ & 11,12 \\
\hline Siganus guttatus & Siganidae & Anisakidae & ، & 4 \\
\hline Saurida isarankurai & Synodontidae & “ & “ & 4 \\
\hline S. longimanus & "، & “" & “ & 4 \\
\hline S. micropectoralis & “ & “ & “" & 4 \\
\hline S. undosquamis & “ & “" & “ & 4 \\
\hline Trichiurus lepturus & Trichiuridae & Anisakis sp. & S Java & 3 \\
\hline
\end{tabular}


as first intermediate hosts. The L3 develops inside the first intermediate host, and larger invertebrates, cephalopods and various fish species serve as transport hosts that acquire the nematodes through the food chain. If small fish and cephalopods are preyed upon by larger fish, the larvae are capable of re-infecting the latter without moulting. Larger fish thus may accumulate enormous numbers of larvae as paratenic or transport hosts (see Jakob \& Palm 2006). The life-cycle is completed when the definitive host preys upon infected crustaceans, cephalopods or fish (Kellermanns et al., 2007). The stomach of the studied $A$. rochei rochei was filled with small crustaceans and only few small sized fish, and D. russelli preyed upon small crustaceans as well. According to Froese and Pauly (2007), the main prey items of both fish species are planktonic crustaceans and small fish, particularly anchovies in the case of the former species. A low intensity of Anisakis in both sampled species together with the observed prey items suggest that the Anisakis larvae uptake originates directly from the crustacean first intermediate hosts (see Palm, 1999), while larger predatory fish ingest them through the clupeid or carangid schooling fish intermediate hosts (Table 4). In all cases, mainly pelagic fish species are infected, suggesting a pelagic life cycle for the tropical $A$. typica.

The observed prevalence and the intensity of infection of A. typica were higher in the scombrid A. rochei rochei compared to the carangid $D$. russelli, assuming that the former species is a better intermediate host for the nematode in Balinese waters. With the former fish being infected during 2005 and 2006, A. typica was readily available throughout the years. The infection level for both fish is much lower than observed for $D$. russelli from northern Javanese waters $(80-100 \%$ prevalence), however, very similar to the infection level of $14.2 \%$ during March and $18.9 \%$ in October 1978 in the Bali Strait (Burhanuddin \& Djamali, 1978). Most other records of anisakids from Indonesian waters are quite old (Table 4), and also recorded a much higher infection rate of $D$. russelli from different places in the Java Sea during the ' 80 s. It cannot be decided at present whether this difference is real and reflects a decrease of Anisakis in Indonesian fish populations that depends on the sampling site or the presence of suitable intermediate or final hosts. Possible reasons for a drop in the fish anisakid load can be seen in a drop of final host numbers, dolphins in the case of $A$. typica, in the region. Further studies are needed to compare the present situation with that of nearly 30 years ago.

The comparison of the infection between the northern and southern Balinese coast demonstrated a higher rate in northern Bali waters compared to the South in 2005. By using anisakid fish parasites as a biological indicator for the final host abundance, the northern $A$. rochei rochei was infected in higher level than the southern fish. In marine anisakids there is a well known relationship between the abundance of the final host population and the infection rates in the fish intermediate hosts (e.g. Palm, 1999). This might also indicate that the dolphin population as the Ani- sakis typica final hosts is higher in northern Balinese waters compared to the South. This is not astonishing since dolphin watching is highly popular in front of Lovina Beach in North Bali, where high local dolphin populations occur.

The present study is the first scientific record of Anisakis from the musculature of a commercial fish from the tourist island Bali. However, the recorded infection in the muscle was low, indicating no major risk for the consumers from the studied fish. Also earlier studies from the Java Sea revealed no significant musculature infection in different Indonesian fish species (Burhanuddin \& Djamali, 1978, 1983; Ilahude et al., 1978), though this might be also a consequence of the sampling procedure. The typical site of infection for Indonesian A. typica is the body cavity and mesentery, followed by specimens in the gonads and the liver. In contrast to the related species Anisakis simplex (s.s.) that also infests the fish musculature as a common site in temperate waters (e.g. Strømnes \& Andersen, 1998, 2003), this seems to be not the case in A. typica. Thus, besides the life cycle and dispersal mechanism, a typical site of infection might be another distinguishing feature among the different Anisakis species or even among sibling species within the Anisakis simplex complex, explaining why $A$. typica to date has not been recorded to cause human anisakiasis.

\section{Acknowledgements}

The study was supported by the German Academic Exchange Service (DAAD), the German Federal Ministry for Education and Science (BMBF Grant No. 03F0391A) within the framework of the joint Indonesian-German research programme SPICE (Science for the Protection of Indonesian Coastal Marine Ecosystems), and the German Research Council (DFG PA 664/4-1) (H.W.P.).

\section{References}

ANDERSON, R. C. (2000): Nematode parasites of vertebrates. Their development and transmission, $2^{\text {nd }}$ edition. CABI Publishing International, Wallingford, p. 650

Asmanelli, Yuliansyah, H., MuCHARI (1993): Penyakit ikan laut di lokasi Keramba Jaring Apung di Kepulauan Riau. [Marine fish diseases in floating net cages in Riau Archipelago.] Prosiding Seminar hasil penelitian perikanan budidaya pantai, 16 - 19 Juli 1993, Maros, Indonesia 11: 13 - 24 (In Indonesian)

Burhanuddin, Djamali, A. (1978): Parasit Anisakis sebagai petunjuk perbedaan populasi ikan laying, Decapterus russelli Ruppell, di laut Jawa. Osean. Indonesia, 9: 1 - 11 Burhanuddin, Djamali, A. (1983): Pengamatan larva Anisakidae pada ikan laut di laut Jawa dan sekitarnya. Osean. Indonesia, 16: $19-27$

Bush, O., Lafferty, A.D., Lotz, J.M., Shostak, A.W. (1997): Parasitology meets ecology on its own terms: Margolis et al. revisited. J. Parasitol., 83: 575 - 583

Farjallah, S., Ben Slimane, B., Busi, M., Paggi, L., 
Amor, N., Blel, H., SAid, K., D’Amelio, S. (2008). Occurrence and molecular identification of Anisakis spp. from the North African coasts of Mediterranean Sea. Parasitol. Res., 102: 371 - 379

Froese, R., PAuly, D. (Eds.) (2007): Fishbase. World Wide Web Electronic publication. www.Fishbase.org, version (03/2007)

Hadidjaja, P., Ilahude, H.D., Mahfudin, B., MALIKUSWORO, H. (1978): Larvae of Anisakidae in marine fish of coastal waters near Jakarta, Indonesia. Am. J. Trop. Med. Hyg., 27: $51-54$

Hutomo, M., Burhanuddin, Hadidjaja, P. (1978): Observations on the incidence and intensity of infection of nematode larvae (Fam. Anisakidae) in certain marine fishes of waters around Panggang Island, Seribu Islands. Mar. Res. Indonesia, 21: $49-60$

ILAHUDE, H. D. (1980): Anisakid larvae in marine fish in Indonesia (A review). Asian Meeting on parasitic infections, February 26-28, Bangkok, Thailand

ILAHUde, H.D., HAdidJAJA, P. AND MAHFudin, B. (1978): Survey on anisakid larvae in marine fish from markets in Jakarta. SE Asian J. Trop. Med. Pub. Health, 9: 48 - 50

ISHIKURA, H., NAMIKI, M. (1989): Gastric Anisakiasis in Japan. Springer, Tokyo

ISHIKURA, H., KIKUCHI, K. (1990): Intestinal Anisakiasis in Japan. Springer, Tokyo

JAKOB, E., PALM, H. W. (2006): Parasites of commercially important fish species from the southern Java coast, Indonesia, including the distribution pattern of trypanorhynch cestodes. Verhandl. Ges. Ichthyol., 5: 165 - 191

Kellermanns, E., Klimpel, S., PAlM, H. W. (2007): Molecular identification of ascaridoid nematodes from the deepsea onion-eye grenadier (Macrourus berglax) from the East Greenland Sea. Deep Sea Res. Part I, 54: 2194 - 2202

Klimpel, S., Palm, H.W., RÜCKert, S., PiatKowski, U. (2004): The life cycle of Anisakis simplex in the Norwegian Deep (northern North Sea). Parasitol. Res., 94: 1 - 9 KoEsharyani, I., RozA, D., MAHARdiKA, K., JoHnNy, F., ZAFRAN, YUASA, K. (2001): Manual for fish disease diagnosis. II. Marine fish and crustacean diseases in Indonesia. Gondol Research Institute for Mariculture. Central Research Institute for Sea Exploration and Fisheries, Department of Marine Affairs and Fisheries and Japan International Cooperation Agency.

LATAMA, G. (2006): [Metazoan parasites from the narrowbarred Spanish mackerel, Scomberomorus commerson (Lacapede, 1800), around Sulawesi waters.] Ph.D. Thesis, Study Program of Aquatic Sciences, Bogor Agricultural University, $140 \mathrm{pp}$. (In Indonesian)

Lester, R. J. G., Thompson, C., Moss, H., Barker, S. C. (2001): Movement and stock structure of narrow- barred Spanish mackerel as indicated by parasites. J. Fish Biol., 59: $833-842$

Mattiucci, S., Paggi, L., Nascetti, G., Portes Santos, C., Costa, G., Di Beneditto, A.P., Ramos, R., Argyrou, M., Cianchi, R., Bullini, L. (2002): Genetic markers in the study of Anisakis typica (Diesing, 1860): larval identification and genetic relationships with other species of
Anisakis Dujardin, 1845 (Nematoda: Anisakidae). Syst. Parasitol., 51: 159 - 170

Mattiucci, S., Nascetti, G., Dailey, M., WebB, S. C., BARROS, N. B., CIANCHI, R., BULliNI, L. (2005): Evidence for a new species of Anisakis (Dujardin, 1845): morphological description and genetic relationships between congeners (Nematoda: Anisakidae). Syst. Parasitol., 61: 157 - 171

Martosewojo, S. (1980): Cacing Anisakis yang hidup sebagai parasit pada ikan laut. Pewarta Oseana, 6 (2): 1 - 5 Moore, B. R., Buckworth, R. C., Moss, H., Lester, R. J. G. (2003): Stock discrimination and movements of narrowbarred Spanish mackerel across northern Australia as indicated by parasites. J. Fish Biol., 63: 765 - 779

NADler, S.A., S., D’ AMElio, S., DAiley, M.D., PAGgi, L., SIU, S., SAKANARI, J. (2005): Molecular phylogenetics and diagnosis of Anisakis, Pseudoterranova, and Contracaecum from the northern Pacific marine mammals. J. Parasitol., 91: 1413 - 1429

PALM, H. W. (1999): Ecology of Pseudoterranova decipiens (Krabbe, 1878) (Nematoda: Anisakidae) from Antarctic waters. Parasitol. Res., 85: 638 - 646

PALM, H. W. (2000): Trypanorhynch cestodes from Indonesian coastal waters (East Indian Ocean). Folia Parasitol., 47: 123 - 134

Palm, H. W. (2004): The Trypanorhyncha Diesing, 1863. PKSPL-IPB Press, Bogor, p. 710

Palm, H. W., WAEschenBaCh, A., LitTlewood, D. T. J. (2007): Genetic diversity in the trypanorhynch cestode Tentacularia coryphaenae Bosc, 1797: evidence for a cosmopolitan distribution and low host specificity in the teleost intermediate host. Parasitol. Res., 101: 153 - 159 Petersen, F., Palm, H. W., Möller, H., Cuzi, M. A. (1993): Flesh parasites of fish from central Philippine waters. Dis. Aquat. Org., 15: $81-86$

RÜCKERT, S. (2006): [Marine Fish Parasites in Indonesia: State of Infestation and Importance for Grouper Mariculture.] PhD-thesis, Heinrich-Heine University of Düsseldorf, Germany. (In German)

StRøMnES, E., ANDERSEN, K. (1998): Distribution of whaleworm (Anisakis simplex, Nematoda, Ascaridoidea) L3 larvae in three species of marine fish; saithe (Pollachius virens (L.)), cod (Gadus morhua L.) and redfish (Sebastes marinus (L.)) from Norwegian waters. Parasitol. Res., 84: $281-285$

Strømnes, E., Andersen, K. (2003): Growth of whaleworm (Anisakis simplex, Nematodes, Ascaridoidea, Anisakidae) third-stage larvae in paratenic fish hosts. Parasitol. Res., 89: $335-341$

SWOFFORD, D. L. (2001): PAUP*: Phylogenetic analysis using parsimony (and other methods), Version 4.0b10. Sinauer Associates, Sunderland, MA

Thompson, J. D., Higgins, D. G., Gibson, T. J., Clustal W. (1994): Improving the sensitivity of progressive multiple sequence alignment through sequence weighting, positions-specific gap penalties and weight matrix choice. Nucleic Acids Res., 22: 4673 - 4680

YAMAGUTI, S. (1952): Parasitic worms mainly from Celebes. Part 1. New digenetic trematodes of fishes. Acta Med. 
Okayama, 8: $146-198$

YAMAGUTI, S. (1953a): Parasitic worms mainly from Celebes. Part 3. Digenetic Trematoda of fishes II. Acta Med. Okayama, 8: $257-295$

YAMAGUTI, S. (1953b): Parasitic worms mainly from Celebes. Part 2. Monogenetic trematodes of fishes. Acta Med. Okayama, 8: $203-256$

YAMAGUTI, S. (1954a): Parasitic worms mainly from Celebes. Part 9. Nematodes of fishes. Acta Med. Okayama, 9: $122-133$

YAmaguti, S. (1954b): Parasitic worms mainly from Celebes. Part 8. Acanthocephala. Acta Med. Okayama, 8: $406-413$

YAMAGUTI, S. (1954c): Parasitic copepods of fishes from Celebes and Borneo. Publ. Seto Mar. Biol. Lab., 3: 375 - 398

YAMAguTI, S. (1954d): Parasitic worms mainly from Celebes. Part 6. Cestodes of fishes. Acta Med. Okayama, 8: $253-374$

RECEIVED JUNE 1, 2007
YuAsa, K., ZaFran, KoEsharyani, Rosa, D., Jonny, F. (1998): Diseases in marine fishes reared at Gondol Research Station for coastal fisheries. Prosiding Seminar Teknologi Perikanan Pantai, 6 - 7 August 1998, Bali, pp. $94-98$

Yuniar, A. T., Palm, H. W., Walter, T. (2007): Crustacean fish parasites from Segara Anakan Lagoon, Java, Indonesia. Parasitol. Res. 100: 1193 - 1204

ZAFran, RoZA, D., JohnNy, F., Koesharyani, I., YuASA, K. (2000): Diagnosis and treatments for parasitic diseases, humpback grouper, Cromileptes altivelis broodstock. Gondol Research Station for Coastal Fisheries, Central Research Institute for Fisheries, Indonesia

Zhu, X., D'Amelio, S., Palm, H. W., Paggi, L., GeorgeNAscimento, M., GASSER, R. B. (2002): SSCP-based identification of members within the Pseudoterranova decipiens complex (Nematoda: Ascaridoidea: Anisakidae) using genetic markers in the internal transcribed spacers of ribosomal DNA. Parasitology, 124: 615-623

ACCEPTED NOVEMBER 22, 2007 